Justin Remhof*

\title{
Nietzsche and James on the Value of Constructing Objects
}

https://doi.org/10.1515/opphil-2018-0028

Received August 3, 2018; accepted October 25, 2018

\begin{abstract}
In this paper, I first suggest that Nietzsche and James, two otherwise very different thinkers, both endorse the controversial constructivist view that human representational practices bring all material objects into existence. I then explore their views concerning why and how constructivism can play a vital role in helping us find reality and our lives valuable.
\end{abstract}

Keywords: Nietzsche, James, objects, metaphysics, constructivism, nihilism, pragmatism, truth, value theory

Nietzsche and James are not commonly thought to endorse any particular metaphysical view of material objects. In fact, they are sometimes not thought to have any substantive metaphysical commitments at all. ${ }^{1}$ They are both much more interested in existential issues concerning the various ways in which we find reality and our lives valuable. But, I suggest, Nietzsche and James do endorse a particular view of objects. And, remarkably, their positions are nearly identical. As I read them, they both endorse the constructivist view that human representational practices, which organize the world in experience, bring objects into existence. ${ }^{2}$ Although neither Nietzsche nor James use the term 'constructivism', they both accept the view-a convergence which is striking. After all, James never read much of Nietzsche, and the radical nature of constructivism makes it a rare position to hold. But their shared commitment to constructivism is interesting for a much different reason-one that has been largely overlooked in the literature. ${ }^{3}$ As I read them, both Nietzsche and James believe that constructivism has positive existential consequences because it plays a vital role in helping us find reality and our lives valuable. This paper focuses on examining some key elements of the value of constructivism in these two thinkers.

Here is the plan. In the first section, I lay out the constructivist views found in Nietzsche and James. I am not concerned with their particular arguments for constructivism, or how they might respond to objections

1 For instance, Berry argues that Nietzsche has no substantive metaphysical commitments. See Berry, Nietzsche and the Ancient Skeptical Tradition. And Seigfried contends that pragmatists such as James should jettison terms like 'metaphysics' when referring to their own positions. See Seigfried, "Pragmatist Metaphysics? Why Terminology Matters."

2 The fact that Nietzsche and James have nearly identical views of material objects is most likely due to the revival of Kant and the influence of neo-Kantianism in the $19^{\text {th }}$ century. For a discussion of Kantian themes in James, see Carlson, "James and the Kantian Tradition.” Unfortunately, Carlson does not address James's Kantian take on material object metaphysics, and instead focuses on James’s Kantian epistemology. See Carlson, “James and the Kantian Tradition,” 366-372. Pihlström correctly identifies Kantian themes in James's metaphysics, but nonetheless claims that for James human practices "do not, of course, construct the world (only a very radical pragmatist would claim they do)" (Pihlström, "Metaphysics with a Human Face," 11). I give reason below to suggest that James is very much this kind of "radical pragmatist" (see also Schwartz, Rethinking Pragmatism, 124-139). For a discussion of how Kantian themes play a crucial role in Nietzsche's view of material objects, see Remhof, Nietzsche's Constructivism, 1-16.

3 For instance, most general accounts of James's philosophy neither address his constructivism nor the value he finds in constructivism, despite the fact that James dedicates an entire lecture of Pragmatism to the topic (see, e.g., Bird, William James; Cooper, The Unity of William James's Thought; Gale, The Philosophy of William James). Schwartz offers a nice account of James's constructivism, but does not address why James finds constructivism valuable. See Schwartz, Rethinking Pragmatism, 124-139.

*Corresponding author: Justin Remhof, Old Dominion University, United States of America; E-mail: jremhof@odu.edu 
to the heterodox position. I have addressed these issues elsewhere. ${ }^{4} \mathrm{My}$ aim is to introduce their views in order to understand the value they find in constructivism, which I develop in the second and third sections of the paper. After describing Nietzsche's position, I argue that he leaves key issues concerning the value of constructivism unresolved, and I turn to James for a more fulfilling account. I finish by showing that Nietzsche accepts the reasons that James offers for finding constructivism valuable, and I suggest that we get a better understanding of Nietzsche's account when we read him through the lens of James. The result should be an informative picture of how Nietzsche and James, two otherwise very different philosophers, come together when approaching the nature and value of constructing objects.

\section{Nietzsche and James on constructivism}

Let me begin by introducing the constructivist views in Nietzsche and James. In The Gay Science, Nietzsche asserts that it is "enough to create new names [...] in order to create new "things"'5. The thought is that creating "names"-or better, concepts-can create objects. "A 'thing' is the sum of its effects," Nietzsche writes, "synthetically united by a concept". To identify an object with "effects" is to identify it with perceivable properties. This position comes from Roger Boscovich, an $18^{\text {th }}$ century physicist. Boscovich anticipates modern point particle physics by arguing that reality is fundamentally comprised of forces, rather than Newtonian matter, such that all properties of the macroscopic world can be accounted for by relations among basic forces. Nietzsche follows Boscovich in taking the properties that constitute objects to be ultimately the perceivable effects of microscopic interactions of forces.

In the passage above, Nietzsche adds that objects are "synthetically united" groups of properties and that unification occurs by the application of concepts. Objects are conceptually unified groups of properties. Take terrestrial planets like Earth or Mars, for example. Terrestrial planets are just particular groups of properties, e.g. being an astronomical object, orbiting the sun, being mostly rock, and so on, which are brought together under the concept <terrestrial planet>. On Nietzsche's account, the properties that constitute material objects like terrestrial planets are empirical. Indeed, he holds that object construction is constrained by what we can encounter in sensory experience. ${ }^{7}$ In experience, Nietzsche contends, we encounter various clusters of properties, but no cluster is a fully unified organization apart from our practices. Such unity occurs in accordance with our needs, interests, and values: "A thing = its qualities; but these equal everything which matters to us about that thing; a unity under which we collect the relations that may be of some account to us"8. Altogether, then, Nietzsche embraces the view that objects are unified groups of empirical properties, which are the effects of force relations we encounter in experience, and that unification occurs through the application of concepts relative to our needs, interests, and values. In this sense, objects are constructed. ${ }^{9}$

James holds a similar position. In Pragmatism ${ }^{10}$, he explains that constructivism is a consequence of the "humanist" view that truth is "man-made"11. For James, we make truth because "we create the

4 See Remhof, "Defending Nietzsche's Constructivism about Objects.” Note also that this article develops themes first introduced in Remhof, Nietzsche's Constructivism, 128-132.

5 Nietzsche, The Gay Science, 58, see also 301. Note that all references to Nietzsche's works refer to section numbers.

6 Nietzsche, Kritische Studienausgabe, 13:14[98].

7 Nietzsche believes that what exists is what can in principle affect us in sensory experience (see Kritische Studienausgabe, 11:5[19]), and that sensory information constrains inquiry that leads to truth (see Beyond Good and Evil, 134; Twilight of the Idols, "Reason" 3).

8 Nietzsche, Kritische Studienausgabe, 12:2[77], cf. The Gay Science, 58.

9 Not everyone agrees that Nietzsche is a constructivist about objects. For three different accounts, see Clark, Nietzsche on Truth and Philosophy; Nola, "Nietzsche’s Naturalism”; Hales and Welshon, Nietzsche’s Perspectivism. See Remhof, Nietzsche’s Constructivism, 17-47, for arguments against these readings.

10 I will not be discussing James's view of constructivism in relation to his radical empiricism, but instead his pragmatism, primarily the material in Lecture VII of Pragmatism, where constructivism takes center stage. Importantly, James writes, "there is no logical connection between pragmatism [and] ... 'radical empiricism'. The latter stands on its own feet. One may entirely reject it and still be a pragmatist” (cited in Schwartz, Rethinking Pragmatism, 6).

11 James, Pragmatism, 110. 
subjects of our true as well as of our false propositions"12. The "subjects" we construct are objects that render propositions truth-evaluable. For it to be true or false that there are four terrestrial planets in our solar system, for instance, we must establish which properties constitute terrestrial planets. James writes that "a thing" is something that we "carve out [...] to suit our human purposes"13. He illustrates this idea by pointing to constellations. We construct constellations by deciding that some set of stars, rather than another, constitutes a constellation. For James, this selective process applies to all objects of experience. Our representations of the heavens, for instance, also determine the specific identity conditions of what constitutes the stars that make up constellations. According to James, we "carve out everything" like we "carve out constellations" in order to utter true statements about the objects of experience ${ }^{14}$.

Like Nietzsche, James holds that objects are constructed from information provided by the senses. James explains that "we break the flux of sensible reality into things"15. Sensory information constrains construction, but such information is not uniquely constraining. James declares, "Now however fixed these elements of reality may be, we still have a certain freedom in our dealings with them. Take our sensations. That they are is undoubtedly beyond our control; but which we attend to, note, and make emphatic in our conclusions depends on our interests" ${ }^{16}$. We have no control over the fact that we are affected in experience, but our concerns dictate which sensations we pay attention to, and this contributes to determining which objects are constructed. James remarks, "The that of [reality] is its own; but the what depends on the which, and the which depends on $u{ }^{\prime \prime 17}$. Applying the demonstrative 'that' does not identify what there is, or what objects there are. Identifying what there is, or what objects there are, requires attending to some portion of experience the boundaries of which are drawn using concepts like <terrestrial planet>, <constellation>, and <star >. Reality is "something resisting," or that which offers resistance, but nonetheless "malleable," or able to be constructed in various ways ${ }^{18}$.

\section{The value of constructivism}

I have provided evidence for thinking that Nietzsche and James are constructivists. Now I want to consider what value constructivism holds for these thinkers. The issue is important because Nietzsche and James do not typically evaluate metaphysical positions merely by determining whether those positions correspond to the way the world is. What is at stake is the value metaphysical positions have for us-why we posit them, and what they do for us. Of course, the fact that some metaphysical position is true matters. But, it will emerge below, James identifies the truth of a position with what that position can do for us, and Nietzsche denies that truth is the only important evaluative standard in inquiry. Nietzsche even holds that we should experiment with depreciating the value of truth, since there are times when other standards, like aesthetic ones, are more appropriate ${ }^{19}$. What should emerge in the next two sections, then, is an account of why embracing constructivism is valuable beyond the fact that it might best reflect the nature of material objects.

12 Ibid., 114. I have argued elsewhere that Nietzsche also embraces this humanist view of truth. See Remhof, "Nietzsche's Conception of Truth.” For another reading that connects James and Nietzsche on truth, in part by way of what I call constructivism, see Fabbrichesi, "Nietzsche and James."

13 James, Pragmatism, 114.

14 Ibid.

15 Ibid.

16 Ibid., 111.

17 Ibid.

18 Ibid., 115.

19 See Nietzsche, On the Genealogy of Morals, III: 24; The Gay Science 373, 344. 


\section{Nietzsche on the value of constructivism}

To understand Nietzsche's view of the value of constructivism, we need to introduce what worries him most: the advent of nihilism. He writes, "For some time now, our whole European culture has been moving as toward a catastrophe" ${ }^{20}$. The catastrophe is nihilism, the position that life is meaningless because the "highest values" that we have used to assess life have become devalued. ${ }^{21}$ To say that our highest values have become devalued is to say that our highest values cannot be realized in the conditions of this world. ${ }^{22}$ That is, what we value most in this world is unattainable, perhaps because realizing such values requires some other world, like heaven. Following Reginster ${ }^{23}$, we can say that the devaluation of our highest values leads to nihilistic despair. Nietzsche names three values, or "categories," that cannot be realized in this world: (i) life has an overall purpose; (ii) there is an ultimate unity to reality; and (iii) there exists a "true world of being," that is, some world ontologically independent of the empirical world which typically illuminates the true nature and meaning of the empirical world. ${ }^{24}$ On Nietzsche's account, embracing any of these leads to nihilistic despair.

Nietzsche's assessment of (i) and (ii) does not concern us here, since the value of constructivism emerges in relation to the value of (iii): the true world. And, importantly, Nietzsche believes the true world to be the most dangerous nihilistic value. ${ }^{25}$ From Plato's Forms to Kant's things in themselves, the true world is the value humanity has most often used to find life meaningful. Plato believes knowledge of the Forms is necessary for the good life, for example, and Kant believes that things in themselves enable faith in God, freedom, and morality. Notice that the world of the Forms and things in themselves, like other true worlds, refer to realities that are constitutively mind-independent. For this reason, Nietzsche holds that even those who dedicate their lives to science and philosophy value the true world, in the sense that they regard the empirical world as having a nature that is ontologically independent of human practices. ${ }^{26}$ Scientists and philosophers commonly believe that our best theories should be those that, at least in part, represent constitutively mind-independent objects. This belief is especially dominant in contemporary analytic material object metaphysics, ${ }^{27}$ and it has recently become popular in continental philosophy, primarily due to the influence of the "speculative realism" and "new realism" movements. ${ }^{28}$ The meaningfulness of our scientific and philosophical pursuits concerning the nature of the objects largely depends on the value of the true world.

But for Nietzsche, such a value is unattainable. If we constitute which properties objects have by virtue of conceptual organization, then our best theories cannot represent objects with a constitutively mindindependent nature. Coming to recognize the truth of constructivism therefore enables us to understand that a longstanding goal of scientific and philosophical pursuits cannot be realized in the conditions of this world. Nietzsche writes, "Nihilism, then, is the recognition of the long waste of strength, the agony of the 'in vain' [...] as if one had deceived oneself all too long" 29 . The traditional aim of revealing a true world is a "long waste of strength," a project undertaken "in vain" that we have been "deceived" about for a long time. Commitment to constructivism helps uncover this deception, and in doing so helps us revalue the aims of scientific and philosophical inquiry.

20 Nietzsche, Kritische Studienausgabe, 13:11[411].

21 Ibid., 12:9[35], see also 13:11[411]. When discussing nihilism, Nietzsche uses meaningless [sinnlos] and valueless [werthlos] interchangeably (see, e.g., Kritische Studienausgabe, 13:11[99]). In what follows, then, I make no distinction.

22 See Kritische Studienausgabe 12:9[60], see also 13:11[61], 13:14[9]; On the Genealogy of Morals, II: 24; Antichrist, 6, 7, 20.

23 Reginster, The Affirmation of Life, 28.

24 Nietzsche, Kritische Studienausgabe, 13:11[99].

25 See Nietzsche, Twilight of the Idols, "Reason” 6; Antichrist, 2, 17; Ecce Homo, P: 2, "Destiny” 8; Kritische Studienausgabe, 12:9[35], 12:9[41], 13:11[99], 13:11[72], 13:14[103].

26 See Nietzsche, On the Genealogy of Morals, III: 24, 25, 11.

27 For two accounts that widely disagree with one another but share this basic aim, see Sider, Writing the Book of the World; Thomasson, Ontology Made Easy.

28 For speculative realism, see Harman, "The Current State of Speculative Realism"; Grant, Philosophies of Nature After Schelling. For new realism, see Ferraris, Manifesto of New Realism, Introduction to New Realism; Gabriel, Fields of Sense.

29 Nietzsche, Kritische Studienausgabe, 13:11[99]. 
This analysis shows that Nietzsche believes constructivism is valuable for overcoming nihilism in two ways. First, recognizing that objects are constructed enables us to understand that the true world has infected our best scientific and philosophical goals. The value of the true world must be exposed and denounced. But this is not enough for overcoming the influence of the value of the true world. We also need a new aim. This can be supplied by constructivism. The constructivist holds that our best theories should attempt to understand the nature of objects as they gain determinate structure in the course of our attempts to understand the world in experience by virtue of representational organization. Embracing constructivism enables scientific and philosophical work to proceed without deception concerning the objects of inquiry. Nietzsche's view of objects not only pushes us to reject the true world, then, it also rejuvenates our cognitive pursuits with new meaning in the wake of that rejection.

I now want to introduce an objection. I think Nietzsche's insight into the value of constructivism for overcoming nihilism needs to go further-and I think he would have to agree. The roles constructivism plays in overcoming nihilism turn on affirming the way the world is. Indeed, Nietzsche remarks, "A nihilist is a man who judges of the world as it is that it ought not to be, and of the world as it ought to be that it does not exist" ${ }^{30}$. Denying constructivism amounts to holding that the way the world is ought not to be, which leads to nihilistic despair. Non-constructivist conceptions of objects cannot be realized in the conditions of this world.

Yet, identifying the value of constructivism with the fact that it reflects the true nature of reality runs into a problem. As I mentioned above, Nietzsche believes that truth alone does not exhaust the value of metaphysical positions. He thinks that we often need to go beyond mere appeal to truth and falsityhe even claims that we should "value more than truth the force that forms, simplifies, shapes, [and] invents"31. Nietzsche holds that a view should be evaluated in relation "to what extent it is life-promoting, life-preserving, species-preserving, perhaps even species-cultivating" 32 . So, he owes us an account of why embracing constructivism might be "life-promoting" or "species-cultivating" beyond the fact that it supplies a correct account of the nature of objects. But it is not obvious that he provides such an account. This weakens the value he finds in constructivism for overcoming nihilism. But the cause is not lost. I suggest that we can turn to James to help resolve the worry.

\section{James on the value of constructivism}

James introduces the value of constructivism by contrasting constructivism with the view that "reality [...] stands ready-made and complete, and our intellects supervene with the one simple duty of describing it as it is already" ${ }^{33}$. Constructivism denies that reality is "ready-made and complete," or determinately structured apart from our representational practices. Our representations do not merely describe reality "as it is already," but are rather "important additions to reality" ${ }^{34}$. Our descriptions add to reality because they organize the sensory manifold into objects. James then asks, “The great question is: does [reality], with our additions, rise or fall in value? Are the additions worthy or un-worthy?" ${ }^{35}$. How might constructivism add value to reality?

The most important way, which we have seen above, is that constructing objects is essential for establishing truth. By constructing the objects of reference of true propositions, "man engenders truths upon [the world]"36. Reality gains value by constructing objects because it gains structure that can be assessed as true and false. Truth, of course, is a valuable standard for assessing reality, and James famously holds the pragmatist position that truth is valuable because it enables successful cognition and action. True

30 Nietzsche, Kritische Studienausgabe, 12:9[60].

31 Ibid., 11:25[505].

32 Nietzsche, Beyond Good and Evil, 4.

33 James, Pragmatism, 115.

34 Ibid.

35 Ibid.

36 Ibid. 
beliefs help us effectively navigate complex experience-truths "lead to consistency, stability and flowing human intercourse" ${ }^{37}$. The structure provided by constructing objects therefore contributes to grounding successful cognition and action. Reality rises in value when we have the ability to successfully navigate our environment by grasping truths about it, and it falls in value when we lack this ability. Creating objects enhances the value of reality when the process contributes to helping us understand true things about it.

The value reality gains by constructing objects arises within significant constraints. Truth is not something that turns on satisfying mere personal preference, for instance. According to James, sensory information provides an important constraint on construction, and the current body of accepted belief adds another. James holds the conservativist view that we should remain committed to previously accepted beliefs and take caution when altering those beliefs by conceptualizing the world in different ways ${ }^{38}$. And conservativism provides another way constructivism adds value to reality. James writes, "And may not previous reality itself be there [...] for the very purpose of stimulating our minds to such additions as shall enhance the universe's total value" ${ }^{39}$. Previously accepted beliefs concerning what exists provide the necessary background context for understanding the creation of new objects-creation is not ex nihilo, but rather a particular reconstruction of previous constructions. Important here is the recognition that our creative nature functions to "enhance the universe's total value" ${ }^{\text {". }}$. James believes that reality increases in value by virtue of our creative efforts because it gains determinate structure by way of those efforts. The nature of reality, according to James, is constitutively dependent on our creative abilities: "In our cognitive as well as in our active life we are creative. We $a d d$, both to the subject and to the predicate part of reality"41. "Reality," he remarks, "is still in the making"42. Our creative practices, which construct objects within constraints, bring value to the world.

James also believes that constructivism adds value to our lives as inquirers. He proclaims that "No one can deny that such a [constructive] role would add both to our dignity and to our responsibility as thinkers" ${ }^{43}$. For James, successful cognition and action are not the result of representing objects apart from us, but of creating and applying the kind of representations that structure experience to help us thrive, both theoretically and practically. Since constructivism holds that we are accountable for organizing the world in such a way that leads to such success, constructivism not only leads to robust forms of epistemic responsibility, but also ontological responsibility. ${ }^{44}$ On James's account, we are answerable to, and accountable for, the nature and existence of objects that comprise the world. This contributes to our dignity, or worth, as inquirers. The sort of dignity manifest in constructing objects is grounded in the possession of certain capacities, such as creativity and responsibility, and because these capacities are valuable, constructivism adds value to our lives. Our ability to construct objects brings special esteem to how we view ourselves in our attempts to understand the world. For this reason, James thinks constructivism "proves a most inspiring notion" ${ }^{35}$. Constructivism not only deepens and enriches the value of reality, then, but also enhances our worth as inquirers.

37 Ibid., 92.

38 See, e.g., James, Pragmatism, 109, 11-112.

39 James, Pragmatism, 115.

40 Ibid.

41 Ibid.

42 Ibid.

43 Ibid.

44 Virtue epistemologists often address forms of epistemic responsibility (see, e.g. Code, Epistemic Responsibility; Montmarquet, Epistemic Virtue and Doxastic Responsibility; Kvanvig, "Virtue Epistemology"), but, most likely due to the fact that constructivism about objects is a rare position in contemporary philosophy, what James seems to understand as ontological responsibility has been largely overlooked. For an account that comes close by focusing on the methodology behind construction, see Goodman, Ways of Worldmaking.

45 James, Pragmatism, 115. 


\section{From James to Nietzsche}

I argued above that Nietzsche's account of the value of constructivism runs into a problem. Embracing constructivism should contribute to overcoming nihilism not merely because such a commitment affirms the way the world is, but rather because constructivism promotes life and the species. I now contend that Nietzsche has the resources to claim that constructivism can play this role because he shares James's view of why constructivism is valuable. Nietzsche, like James, believes that constructivism contributes to bringing new value to reality and our lives.

James holds that constructivism does not just provide a true account of the nature of objects, but that having a true account of the nature of objects adds value to the world because it enables us to understand the world. Nietzsche agrees. For example, he says that "we can comprehend only a world that we ourselves have made" ${ }^{\text {46 }}$, and we saw above that successful comprehension of the world contributes to overcoming scientific and philosophical commitment to the true world. Nietzsche and James nonetheless differ on what they believe constitutes successful comprehension of the world. James thinks such success is constituted by grasping truths because truths enable successful thought and action, whereas Nietzsche denies that successful comprehension is constituted by gasping truths because he denies that truth always enables successful thought and action. For instance, Nietzsche holds that falsehoods, such as employing approximate measurements, assuming the existence of perfectly straight lines, and taking there to be exactly identical objects, often enable successful thought and action. ${ }^{47}$ Thus, while James believes constructivism adds value to reality because it renders truth possible and truth is always valuable, Nietzsche believes constructivism adds value to reality because it renders comprehension possible, but comprehension includes positing felicitous falsehoods. Nonetheless, Nietzsche and James agree that constructivism brings value to reality because it supplies the requisite path for understanding it.

Nietzsche also shares with James the view that our creative practices increase reality's value. For Nietzsche, creativity adds value to reality because it leads to the establishment of new ways to find reality meaningful. This is vital in the wake of the devaluation of our highest values. We saw above that James believes that embracing the constructivist view that our creative efforts bring objects into existence affirms our nature as creative beings and shows that our creative practices play a large part in structuring the world. Similarly, Nietzsche writes that our ability to "create the world" is "our best power," and recognizing that "we have created the world that concerns human beings" leads us to being more "proud" and "happy"48. The creativity manifest in constructivism brings new meaning to the world and our engagement with it. This can push back against the meaninglessness associated with nihilistic despair.

Constructivism also exemplifies creativity because constructivism itself can be understood as a new theoretical value created and posited to help us understand the world. Both Nietzsche and James hold that values are created-they are not simply part and parcel of the natural environment. As Nietzsche writes, "Whatever has value in the present world has it not in itself, according to its nature-nature is always value-less-but has rather been given, granted value, and we were the givers and granters!"49. Giving and granting value to reality is imperative for overcoming nihilism. The process creates new structures and possibilities of meaning and significance in the wake of losing our highest values. Developing an understanding of how and why objects are constructed helps us confront the growing frustration that surfaces from coming to understand that the traditional aim of our scientific and philosophical pursuits is bankrupt. By developing a constructivist view of objects, we gain a value that gives new meaning to how we understand the world. Against a longstanding tradition, we should aim to understand objects as constitutively mind-dependent, not as constitutively mind-independent. Constructivism brings value to reality, then, because it illustrates our ability to create new theoretical values that contribute to the advancement of scientific and philosophical inquiry.

46 Nietzsche, Kritische Studienausgabe, 11:25[470]; cf. The Gay Science, 301.

47 See, e.g., Nietzsche, Human, All Too Human, I: 9; The Gay Science, 110, 121. For a recent excellent account of how such falsehoods can be valuable for understanding the world, see Elgin, True Enough.

48 Nietzsche, The Gay Science, 301.

49 Ibid. 
Finally, Nietzsche can follow James in holding that commitment to constructivism adds value to our lives because such a commitment shows the importance of embracing values like epistemic and ontological responsibility when doing science and philosophy. Unlike James, however, Nietzsche never openly connects the fact that we construct objects with the fact that fruitful construction requires embodying values that add to our worth as thinkers. Nonetheless, Nietzsche does embrace certain values that he thinks should guide our lives as inquirers, especially after the value of the true world falls away, and I suggest that there is good reason to suppose that these values support a commitment to constructivism.

For instance, consider what Nietzsche calls the "intellectual conscience." The intellectual conscience is a habit of mind which involves traits such as open-mindedness, courage, caution, humility, analytical autonomy, and practical wisdom ${ }^{50}$. These traits should be understood as virtues of successful cognizers that guide theoretical activities, such as, for instance, organizing data into particular patterns or deciding which variables to hold constant when testing hypotheses. Nietzsche holds that a person with an intellectual conscience stands back and questions "the whole marvelous uncertainty and ambiguity of existence" ${ }^{51}$, and they do so with the knowledge that our practical activities "continually make something that is not yet there," knowing that our creations are often "translated into flesh and reality"52. Someone with an intellectual conscience understands that the world is not determinately structured prior to our interaction with it because our efforts constitute such structure. For Nietzsche, then, having an intellectual conscience includes having the awareness that we are responsible for organizing the world in the course of understanding it, and since having an intellectual conscience brings value to our lives as inquirers, so does endorsing constructivism.

\section{Summary and conclusion}

Let me summarize and conclude. I have suggested that Nietzsche and James are constructivists and that they take commitment to constructivism to have positive existential consequences. Nietzsche believes that embracing constructivism can help us respond to nihilism, specifically the meaninglessness of our cognitive project once we realize that our best scientific and philosophical theories cannot represent constitutively mind-independent objects. Affirming constructivism enables us to understand that clinging to the value of the true world leads to nihilistic despair and that our scientific and philosophical pursuits can be perfectly successful without such a value. These positive roles turn on affirming reality as it is. But I have argued that Nietzsche must hold that overcoming nihilism also involves embracing theoretical positions that add value to reality and our lives. James finds such value in constructivism. He holds that constructivism adds value to reality because it enables successful thought and action and shows that the world's structure is deeply connected to our creative nature, and constructivism adds value to our lives because it leads to us to develop new values, specifically new forms of responsibility and dignity, which enrich our theoretical practices. I have suggested that Nietzsche thinks constructivism adds value to reality and our lives in similar ways. The reasons that James finds constructivism valuable, then, are reasons that Nietzsche can embrace in order to launch a more compelling response to nihilism. There is therefore an uncanny connection not only between the constructivist view of objects that Nietzsche and James endorse, but also between the value these thinkers find in constructivism.

\section{References}

Bird, Graham. William James. London: Routledge and Kegan Paul, 1986.

Berry, Jessica. Nietzsche and the Ancient Skeptical Tradition. Oxford: Oxford University Press, 2010.

50 See Nietzsche, The Gay Science, 2, 4; On the Genealogy of Morals, III: 12; Beyond Good and Evil, 294; Human, All Too Human, P: 6.

51 Nietzsche, The Gay Science, 2.

52 Ibid., 301. 
Carlson, Thomas. “James and the Kantian Tradition.” In The Cambridge Companion to William James, edited by Ruth Anna Putnam, 363-384. Cambridge: Cambridge University Press, 1997.

Clark, Maudemarie. Nietzsche on Truth and Philosophy. Cambridge: Cambridge University Press, 1990.

Code, Loraine. Epistemic Responsibility. Hanover, NH: University Press of New England, 1987.

Cooper, Wesley. The Unity of William James's Thought. Nashville: Vanderbilt University Press, 2002.

Elgin, Catherine. True Enough. Cambridge, MA: MIT Press, 2017.

Fabbrichesi, Rossella. "Nietzsche and James. A pragmatist hermeneutics." European Journal of Pragmatism and American Philosophy (2009), 25-40.

Ferraris, Maurizio. Manifesto of New Realism, trans. Sarah De Sanctic. Albany: State University of New York Press, 2015. Ferraris, Maurizio. Introduction to New Realism, trans. Sarah De Sanctic. London: Bloomsbury, 2015.

Gabriel, Markus. Fields of Sense: A New Realist Ontology. Edinburgh: Edinburgh University Press, 2015.

Gale, Richard. The Philosophy of William James: An Introduction. Cambridge: Cambridge University Press, 2005.

Goodman, Nelson. Ways of Worldmaking. Indianapolis: Hackett Publishing Company, 1978.

Grant, Ian Hamilton. Philosophies of Nature After Schelling. London: Continuum Press, 2008.

Hales, Steven D. and Rex Welshon. Nietzsche's Perspectivism. Urbana: University of Illinois Press, 2000.

Harman, Graham. "The Current State of Speculative Realism.” Speculations: A Journal of Speculative Realism, Vol. IV (2013), 22-28.

James, William. Pragmatism, edited by Bruce Kuklick. Indianapolis: Hackett Publishing Company, 1981 [1906-1907]). Kvanvig, Jonathan. “Virtue Epistemology." In The Routledge Companion to Epistemology, edited by Sven Bernecker and Duncan Pritchard, 199-207. New York: Routledge, 2011.

Montmarquet, James. Epistemic Virtue and Doxastic Responsibility. Lanham, MD: Rowman and Littlefield, 1993.

Nietzsche, Friedrich. Beyond Good and Evil, translated by Walter Kaufmann. New York: Vintage Books, 1989 [1886].

Nietzsche, Friedrich. Ecce Homo, translated by Walter Kaufmann. New York: Vintage Books, 1989 [1908].

Nietzsche, Friedrich. The Gay Science, translated by Josefine Nauckoff, edited by Bernard Williams. Cambridge: Cambridge University Press, 2001 [1882].

Nietzsche, Friedrich. On the Genealogy of Morals, translated by Walter Kaufmann. New York: Vintage Books, 1989 [1887]. Nietzsche, Friedrich. Human, All Too Human, translated by R.J. Hollingdale. Cambridge: Cambridge University Press, 1996 [1878].

Nietzsche, Friedrich. Twilight of the Idols, translated by Duncan Large. Oxford: Oxford University Press, 1998 [1889].

Nietzsche, Friedrich. Kritische Studienausgabe, edited by Giorgio Colli and Mazzino Montinari. Berlin: Walter de Gruyter, 1988.

Nola, Robert. “Nietzsche's Naturalism: Science and Belief.” In Nietzsche, Epistemology, and Philosophy of Science, edited by Babich Babette and Robert Cohen, 91-100. Dordrecht: Kluwer Academic Publishers, 1999.

Pihlström, Sami. "Metaphysics with a Human Face: William James and the Prospects of Pragmatist Metaphysics." William James Studies, Vol. 2 (2007), 1-66.

Register, Bernard. The Affirmation of Life. Cambridge, MA: Harvard University Press, 2006.

Remhof, Justin. Nietzsche's Constructivism. New York: Routledge, 2017.

Remhof, Justin. “Defending Nietzsche’s Constructivism about Objects.” In European Journal of Philosophy, Vol. 25:4 (2017), 1132-1158.

Remhof, Justin. “Nietzsche's Conception of Truth: Correspondence, Coherence, or Pragmatist?” In The Journal of Nietzsche Studies, Vol. 46:2 (2015), 239-248.

Schwartz, Robert. Rethinking Pragmatism: From William James to Contemporary Philosophy. Malden: Blackwell, 2012.

Seigfried, Charlene. "Pragmatist Metaphysics? Why Terminology Matters." Transactions of the Charles S. Peirce Society, Vol. 37 (2001), 13-21.

Sider, Theodore. Writing the Book of the World. Oxford: Oxford University Press, 2011.

Thomasson, Amie. Ontology Made Easy. Oxford: Oxford University Press, 2015. 